\title{
EFISIENSI RELATIF PERGURUAN TINGGI NEGERI DI INDONESIA: PENDEKATAN DATA ENVELOPMENT ANALYSIS (DEA)
}

\author{
Ngatindriatun dan Hertiana Ikasari*
}

Universitas Dian Nuswantoro Semarang

\begin{abstract}
The purpose of this paper is to analyze the relative efficiency of 25 Indonesian State Universities in the period of 2002 to 2006. The analysis used in this research was Data Envelopment Analysis (DEA) with the A.T Flegg, D.O Allen, K. Field and T.W. Thurlow's model. The input variables used were the number of staff, the number of undergraduate students and the number of postgraduate students. The output variables used were the number of undergraduate alumni and the number of postgraduate alumni. The result was there were many Indonesian state Universities which is significantly efficient in the period of 2002 to 2006.
\end{abstract}

Key words: efficiency, DEA, state universities

\section{Pendahuluan}

Otonomisasi kampus merupakan perkembangan baru yang sangat signifikan berkenaan dengan dunia pendidikan tinggi Indonesia. Signifikansi ini berkaitan dengan kenyataan kuatnya intervensi politik terhadap perguruan tinggi sehingga tradisi akademik cenderung terkooptasi oleh dunia politik. Oleh karena itu peluang otonomisasi kampus saat ini seharusnya disambut dan ditindaklanjuti secara bijak oleh dunia perguruan tinggi.

Otonomi pendidikan khususnya otonomi perguruan tinggi yang dasar hukumnya adalah Peraturan Pemerintah No. 61 tahun 1999 yang muncul bersamaan dengan ketentuan otonomi daerah sebenarnya mengandung hal-hal yang positif. Otonomi itu sendiri dapat diartikan suatu keadaan yang independen, bebas atau tidak terikat. Dalam konteks pendidikan khususnya perguruan tinggi otonomi itu dapat dikaitkan dengan kebebasan akademik yang artinya sebuah institusi perguruan tinggi bebas mengelola pendidikannya sendiri sesuai dengan tujuan pendidikan yang ingin dicapainya.

Bagi Perguruan Tinggi Negeri (PTN) yang selama ini masih tergantung dari pemerintah, dengan adanya otonomi maka PTN harus bisa menjalankan sistem pendidikan secara mandiri dengan tidak sepenuhnya lagi bergantung kepada pemerintah. Otonomi ini juga dianggap sebagai tuntutan kemajuan zaman bahkan persiapan menuju era globalisasi dan pasar bebas yang akan segera datang. Singkatnya, otonomi PTN atau otonomi kampus memiliki tujuan untuk mewujudkan sistem pendidikan yang lebih baik demi menghasilkan kualitas sumber daya manusia Indonesia yang handal di masa mendatang.

Tetapi otonomi kampus yang belum sepenuhnya berjalan dan masih lebih banyak berada dalam tataran konsep telah menimbulkan permasalahan-permasalahan, khususnya ketidaksetujuan pada banyak kalangan mahasiswa. Walaupun dalam otonomi banyak aspek yang mempengaruhi sistem pendidikan, namun yang paling banyak disorot dalam otonomi kampus adalah permasalahan yang sangat klasik yaitu soal dana. Dengan adanya otonomi yang diartikan penghentian ketergantungan kepada pemerintah, juga diartikan bahwa perguruan tinggi harus dapat mencari sumber pendanaan sendiri untuk menjalankan pendidikannya. Masalahpun timbul, karena untuk mencukupi anggaran dana untuk pendidikannya, perguruan tinggi terpaksa harus menaikkan biaya pendidikan, dan inilah yang diprotes kalangan mahasiswa dan menganggap otonomi malah menimbulkan beban yang berat dari segi finansial karena ketidakkreatifan dari birokrat kampus dalam mencari dana dan akhirnya dibebankan kepada mahasiswa. 
Tujuan penelitian ini adalah untuk menganalisis efisiensi Perguruan Tinggi Negeri (PTN) di Indonesia setelah diberlakukannya otonomi kampus.

\section{Kerangka Teoritis dan Pengembangan Hipotesis}

Teori Produksi

Tati SJ dan Fathorrozi (2003) menyatakan bahwa produksi merupakan hasil akhir dari proses atau aktivitas ekonomi dengan memanfaatkan beberapa masukan atau input. Hubungan teknis antara input dan output tersebut dalam bentuk persamaan, tabel atau grafik merupakan fungsi produksi (Salvatore 1996). Sehingga fungsi produksi dapat didefinisikan sebagai suatu persamaan yang menunjukkan jumlah maksimum output yang dihasilkan dengan kombinasi output tertentu.

Pada umumnya terdapat dua pengertian mengenai produksi, yaitu pengertian produksi secara ekonomis dan produksi secara fisik/ teknis. Secara ekonomis produksi didefinisikan sebagai kegiatan untuk menaikkan nilai tambah pada suatu barang, baik melalui penambahan guna bentuk (form utility), guna waktu (time utility) dan guna tempat (place utility). Sedangkan secara teknis/ fisik, produksi didefinisikan sebagai hubungan antar factorfaktor produksi yang disebut input dengan hasil produksi yang disebut output (Sudarsono, 1984)

Dengan beberapa definisi tersebut, maka hubungan antara input dan output dalam proses produksi tersebut dapat diformulasikan dalam sebuah fungsi produksi yang menurut Soekartawi (2003) dinyatakan bahwa fungsi produksi adalah hubungan fisik antara variabel yang dijelaskan ( $Y$ ) dan variabel yang mejelaskan (X), di mana variabel yang dijelaskan biasanya berupa output dan variabel yang menjelaskan biasanya berupa input.

Dari input yang tersedia setiap perusahaan ingin memperoleh hasil yang maksimal sesuai dengan tingkat teknologi yang tertinggi pada saat itu (Nicholson 1999). Fungsi produksi dapat memebeikan gambaran kepada kita tentang produksi yang efisien secara teknis yang artinya semua penggunaan input dalam produksi serba minimal atau serba efisien Efisiensi

Ditinjau dari teori ekonomi terdapat 3 (tiga) pengertian efisiensi, yaitu efisiensi teknik, efisiensi harga, dan efisiensi ekonomi (Yotopoulos dan Nugent dalam Soekartawi 2003). Efisiensi ekonomi merupakan produksi dari efisiensi teknik dan harga sehingga efisiensi ekonomis dapat tercapai jika efisiensi teknik dan harga dapat tercapai (Farrel dalam Indah Susantun 2000). Nicholson (1999) juga menyatakan bahwa efisiensi ekonomi memiliki sudut pandang makro dengan jangkauan yang lebih luas dibandingkan dengan efisiensi teknik yang bersudut pandang mikro di mana pengukuran efisiensi teknik cenderung lebih terbatas pada hubungan teknis operasional dalam proses konversi input menjadi output dan akibatnya usaha untuk meningkatkan efisiensi teknis hanya dilakukan dengan kebijakan mikro yang memiliki sifat internal, yaitu dengan pengendalian dan alokasi sumber daya secara optimal. Sedangkan dalam efisiensi ekonomi, harga tidak dianggap given, karena harga dapat dipengaruhi oleh kebijakan makro. Indah Susantun (2000) menyatakan bahwa pengertian efisiensi dalam produksi adalah perbandingan output dan input berhubungan dengan tercapainya output maksimum dengan sejumlah input, artinya apabila rasio output/input besar maka efisiensi dikatakan tinggi.

Soekartawi (1990) mengartikan efisiensi sebagai upaya penggunaan input yang sekecilkecilnya untuk mendapatkan produksi yang sebesar-besarnya, di mana situasi tersebut dapat terjadi apabila proses produksi membuat suatu upaya kalau nilai produk marginal untuk suatu input sama dengan harga input tersebut. 
Efisiensi relatif adalah efisiensi yang bersifat relatif di antara unit-unit yang diamati, dalam evaluasinya, suatu unit dikatakan efisien secara relatif jika unit tersebut efisien dibandingkan unit yang lain. Dalam pengukuran efisiensi relatif, nilai input-output suatu unit memiliki ciri yang lebih atau kurang dibanding unit yang lain tanpa dapat mengatakan seberapakah kurang atau lebihnya.

Penelitian Terdahulu

Dengan menggunakan pendekataan DEA, Melville L. McMillan dan Debasish Datta (1998) meneliti efisiensi relatif 45 universitas yang ada di Canada pada tahun 1992-1993. Variabel input yang digunakan adalah jumlah fakultas dan pengeluaran institusi. Variabel output yang digunakan adalah penelitian dan Iulusan. Hasil yang diperoleh adalah secara kesuluruhan hampir sebagian besar universitas mempunyai nilai efisiensi yang relatif tinggi

Staffan Waldo (2002) meneliti efisiensi 851 sekolah negeri di Swedia pada tahun 1994/1995 dengan pendekatan DEA dan model Tobit. Variabel input yang digunakan adalah jumlah jam mengajar guru dan jumlah murid. Variabel output yang digunakan adalah nilai untuk 3 (tiga) mata pelajaran yang penting di Swedia, antara lain: bahasa Swedia, matematika dan bahasa Inggris. Hasil yang diperoleh adalah karakteristik guru justru tidak berpengaruh terhadap efisiensi, melainkan persaingan dengan sekolah swasta.

A.T.Flegg, D.O. Allen, K.Field dan T.W Thurlow (2004), dengan menggunakan pendekatan DEA dan Malmquist meneliti efisiensi 45 universitas di Inggris. Variabel output yang digunakan adalah pendapatan dari penelitian dan konsultasi, jumlah lulusan mahasiswa S1, jumlah IUlusan mahasiswa S2 dan S3. Variael input yang digunakan adalah jumlah staf (akademik dan non akademik), jumlah mahasiswa S1, jumlah mahasiswa S2 dan S3, dan pengeluaran keseluruhan institusi.

\section{Kerangka Teoritis}

Dalam penelitian dengan metode DEA, maka penentuan variabel merupakan langkah awal sebelum pengolahan data dilakukan, selanjutnya ditentukan pula model output data yang dilakukan dengan membandingkan hasil nilai efisiensi relative model CCR lebih banyak yang sama dengan model VRS, maka model CCR sudah cukup, namun bila tidak, maka dipilih pengolahan data DEA dengan model VRS (Erwinta Siswadi dan Wilson Arafat, 2004) 


Input:
Jumlah dosen
Jumlah mahasiswa S1
Jumlah mahasiswa S2
dan S3
Output:
Jumlah lulusan S1
Jumlah Lulusan S2 dan
S3

Pengukuran efisiensi sebagai ukuran kinerja menentukan jenis input dan output yang mempengaruhi kinerja efisiensi

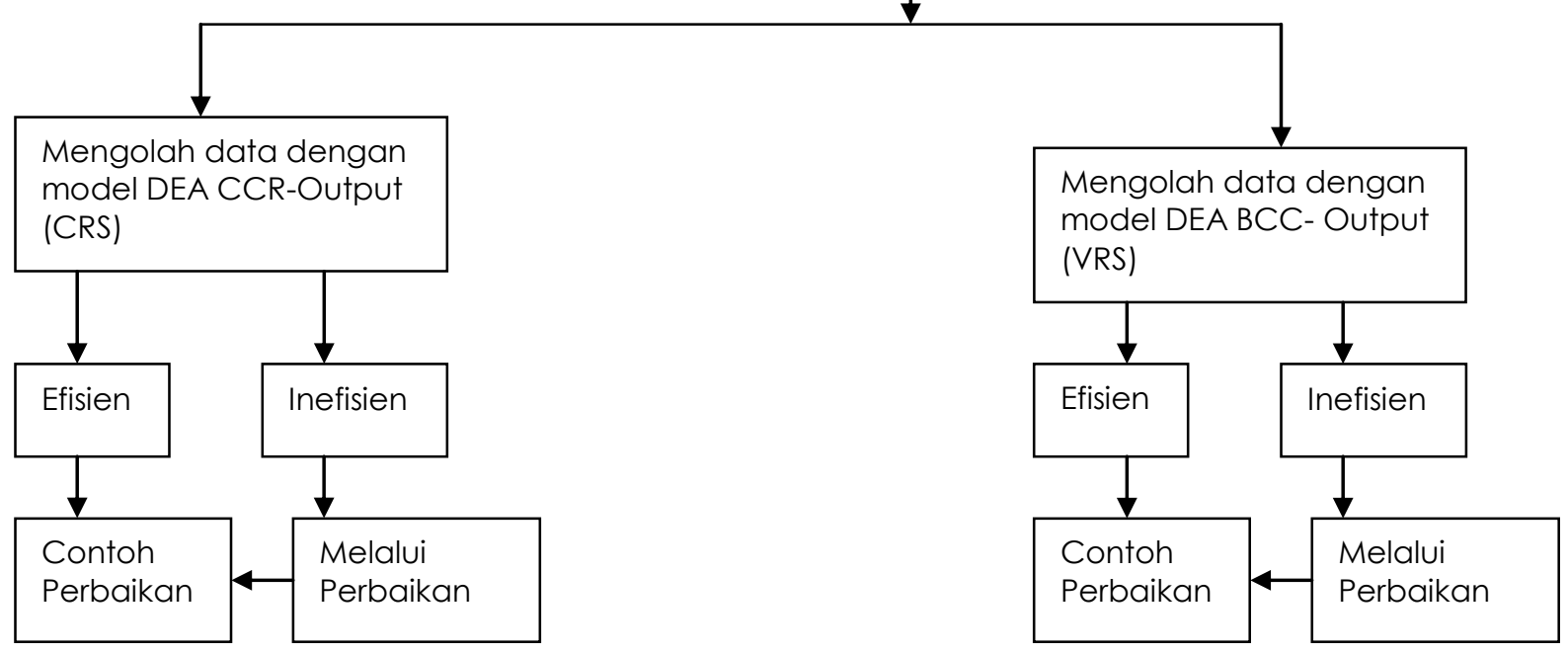

Gambar 1 Kerangka Pemikiran Teoritis

Sumber: Erwinta Siswadi dan Wilson Arafat (2004)

\section{Metode Penelitian}

\section{Data Sampel}

Populasi dalam studi ini adalah perguruan tinggi negeri di Indonesia yang berjumlah 82 PTN. Sumber data diambil dari Evaluasi Program Studi Berbasis Evaluasi Diri (EPSBED) dari tahun 2002 sampai dengan 2006. Data sampel yang digunakan adalah 54 perguruan tinggi negeri di Indonesia yang meliputi 48 universitas negeri, 6 (enam) institut dan 2 (dua) sekolah tinggi. Didalam perkembangannya, sampel yang bisa diambil hanya 25 PTN di Indonesia. Hal ini dikarenakan keterbatasn data. Banyak diantara PTN yang tidak mengisi dengan lengkap data yang ada di EPSBED.

\section{Definisi Operasional Variabel}

Variabel input dalam penelitian ini meliputi: Jumlah dosen, jumlah mahasiswa S1, jumlah mahasiswa S2 dan S3. Sedangkan Variabel output dalam penelitian ini meliputi: jumlah Iulusan S1, serta jumlah lulusan S2 dan S3. Variabel yang digunakan di atas sesuai dengan variabel dari penelitian A.T. Flegg, D.O Allen dan K. Thurlow. Variabel yang tidak bisa disertakan dalam penelitian ini adalah variabel pengeluaran institusi dan pendapatan dari penelitian serta konsultasi karena ketiadaan data. Sementara Variabel jumlah staff yang meliputi staf akademik dan non akademik, diproxy dengan jumlah dosen.

\section{Teknik Analisis Data}

Dalam hal pengukuran efisiensi lazim digunakan 2 (dua) metode, yaitu analisis rasio parsial dan analisis regresi berganda (Samsubar Saleh, 1999). Namun untuk mengukur efisiensi 
relative suatu Unit Kegiatan Ekonomi (UKE) yang memiliki banyak input dan output maka dapat dipakai metode Data Envelopment Analysis (DEA) yang memiliki kelebihan mampu mengatasi kekurangan analisis efisiensi secara rasio dan regresi berganda di mana analisis rasio hanya mampu memberikan informasi bahwa UKE tertentu memiliki kemampuan satu jenis input ke satu jenis output tertentu sedangkan analisis regrsi berganda adalah dengan menggabungkan banyak output menjadi satu.

Metode DEA dirancang untuk mengukur efisiensi relative suatu UKE yang menggunakan input dan output yang lebih dari satu yang mana penggabungan tersebut tidak perlu dilakukan. Efisiensi relative suatu UKE adalah efisiensi suatu UKE dibandingkan UKE lain dalam sampel yang menggunakan jenis input dan output yang sama.

Data Envelopment Analysis (DEA) adalah sebuah metode optimasi program matemtika yang dipergunakan untuk mengukur efisiensi teknis suatu Unit Kegiatan Ekonomi (UKE) dan membandingkan secara relative terhadap UKE yang lain (Charnes et al. 1978; Banker et al. 198 dalam Etty Puji Lestari 2001).

Terdapat 3 (tiga) manfaat dari pengukuran efisiensi dengan menggunakan metode DEA, yaitu, pertama sebagai tolok ukur untuk memperoleh efisiensi relative yang berguna untuk memudahkan perbandingan antar unit ekonomi yang sama; kedua untuk mengukur berbagai informasi efisiensi antar UKE sebagai bahan untuk mengidentifikasi faktor-faktor penyebabnya dan ketiga untuk menentukan implikasi kebijakan dalam meningkatkan efisiensi.

DEA adalah metode dan bukan model yang mana hal ini dapat dijelaskan bahwa metodologi DEA merupakan sebuh metode non parametric yang menggunakan model program linier untuk menghitung perbandingan rasio input-output untuk semua unit yang dibandingkan. Metode ini tidak memerlukan fungsi produksi dan hasil perhitungannya disebut nilai efisiensi relatif (Erwinta Siswadi dan Wilson Arafat 2004).

Dalam metode DEA, efisiensi relatif suatu UKE didefinisikan sebagai rasio dari total output tertimbang dibagi dengan total input tertmbang sehingga inti dari metode DEA adalah menentukan bobot (weights) atau timbangan untuk setiap input dan output UKE di mana bobot tersebut memiliki sifat tidak negatif serta bersifat universal yang artinya setiap UKE dalam sampel harus dapat menerapkan seperangkat bobot yang sama untuk mengevaluasi rasionya dan rasio tersebut tidak lebih dari 1 (Satu) (Samsubar Saleh 1999).

Pada penelitian ini penulis memilih menganalisis kinerja efisiensi dengan pendekatan DEA multi stage. Dalam DEA multi stage, ada dua pendekatan scale, yaitu Constant return to scale (CRS) dan Variabel return to scale (VRS). Formula DEA dimulai dari formula sederhana yang ada di linear programming, yaitu sebagai berikut (Denizer dan Dinc 2000):

Maximize

$$
h_{j}=\frac{\sum_{r=1}^{s} u_{r} Y_{r j}}{\sum_{i=1}^{m} v_{i} x_{i j}}
$$

Kendala $\quad \frac{\sum_{r=1}^{s} u_{r} y_{r j}}{\sum_{i=1}^{m} v_{i} x_{i j}} \leq 1$ dimana $\mathbf{j}=\mathbf{1}, \mathbf{2}, \ldots, \mathbf{n}$

$v_{i} \geq 0$ dimana $i=1,2, \ldots, m$ dan $u_{r} \geq 0$ dimana $r=1,2, \ldots, s$ 
dimana:

hj = nilai efisiensi peguruan tinggi $j$

$r=$ output

$i=$ input

$U_{r}=$ bobot output $r$ yang dihasilkan oleh perguruan tinggi negeri $j$

$y_{r j}=$ jumlah output $r$, dihasilkan oleh perguruan tinggi negeri, dihitung dari $r=1$ hingga $s$

$v_{i}=$ bobot input $i$ yang dihasilkan oleh perguruan tinggi negeri

\section{Hasil dan Pembahasan}

Dari data yang ada kemudian dimasukkan data actual input dan output dengan software BANXIA Frontier menggunakan model CCR dan BCC. Hasil pengolahan tersebut dipergunakan untuk menentukan model analisis selanjutnya dari segi fokus manajerial yaitu dengan menentukan model pengolahan data secara output orientation, yaitu meneliti penambahan output yang dapat dilakukan dengan tingkat input yang ada saat ini meskipun hasil metode DEA dapat menghasilkan pula pengurangan input.

Dalam pengolahan data maka setelah penetapan data input dan output serta penentuan model orientasinya, kemudian hasil analisis dengan model CCR (Model Constant Return to Scale) input maupun model BCC (Model Varying Return to Scale) input dibandingkan. Di bawah ini akan disajikan pembahasan hasil tiap tahun

Tabel 1

Perbandingan Hasil Pengolahan Model CRS dan Model VRS Tahun 2002

\begin{tabular}{lrr}
\hline Unit Nama & Pengolahan Model CRS & Pengolahan Model VRS \\
\hline Universitas Nusa Cendana & 100.00 & 80.9 \\
Universitas Andalas & 100.00 & 100.00 \\
Universitas Gadjah Mada & 100.00 & 100.00 \\
Universitas Sumatera Utara & 100.00 & 100.00 \\
Universtas Brawijaya & 100.00 & 65.6 \\
Universitas Jember & 100.00 & 100.00 \\
Universitas Lampung & 100.00 & 100.00 \\
Universitas Mulawarman & 100.00 & 100.00 \\
Universitas Negeri Padang & 100.00 & 93.3 \\
Universitas Pendidikan Indonesia & 100.00 & 100.00 \\
Universitas Tanjungpura & 100.00 & 100.00 \\
Institut Teknologi Bandung & 100.00 & 100.00 \\
Institut Teknologi Sepulun November & 100.00 & 90.9 \\
Universitas Negeri Medan & 100.00 & 100.00 \\
Universitas Negeri Yogyakarta & 100.00 & 100.00
\end{tabular}

Sumber: Evaluasi Program Studi Berbasis Evaluasi Diri (EPSBED), data diolah, 2008

Tabel 2

Perbandingan Hasil Pengolahan Model CRS dan Model VRS Tahun 2003

\begin{tabular}{lrr}
\hline Unit Nama & Pengolahan Model CRS & Pengolahan Model VRS \\
\hline Universitas Nusa Cendana & 100.00 & 97.9 \\
Universitas Andalas & 100.00 & 100.00 \\
Universitas Gadjah Mada & 100.00 & 100.00 \\
Universitas Indonesia & 100.00 & 100.00 \\
Universitas Sumatera Utara & 100.00 & 65.6 \\
Universtas Brawijaya & 100.00 & 100.00 \\
Universitas Jember & 100.00 & 100.00 \\
Universitas Negeri Malang & 100.00 & 84.3 \\
Universitas Negeri Padang & 100.00 & 70.4 \\
Universitas Pendidikan Indonesia & 100.00 & 100.00 \\
Universitas Tanjungpura & 100.00 & 100.00 \\
\hline
\end{tabular}




\begin{tabular}{lrr}
\hline Institut Teknologi Bandung & 100.00 & 100.00 \\
Institut Teknologi Sepuluh November & 100.00 & 50.9 \\
Universitas Negeri Jakarta & 100.00 & 100.00 \\
Universitas Negeri Medan & 100.00 & 36.8 \\
Universitas Negeri Yogyakarta & 100.00 & 70.9
\end{tabular}

Sumber: Evaluasi Program Studi Berbasis Evaluasi Diri (EPSBED), data diolah, 2008

Tabel 3

Perbandingan Hasil Pengolahan Model CRS dan Model VRS Tahun 2004

\begin{tabular}{lrr}
\hline Unit Nama & Pengolahan Model CRS & Pengolahan Model VRS \\
\hline Universitas Nusa Cendana & 100.00 & 85.3 \\
Universitas Andalas & 100.00 & 100.00 \\
Universitas Diponegoro & 100.00 & 100.00 \\
Universitas Gadjah Mada & 100.00 & 100.00 \\
Universitas Indonesia & 100.00 & 100.00 \\
Universitas Lambung Mangkurat & 100.00 & 90.3 \\
Universitas Sumatera Utara & 100.00 & 100.00 \\
Universtas Brawijaya & 100.00 & 100.00 \\
Universitas Jember & 100.00 & 94.3 \\
Universitas Jenderal Soedirman & 100.00 & 100.00 \\
Universitas Lampung & 100.00 & 100.00 \\
Universitas Mulawarman & 100.00 & 100.00 \\
Universitas Negeri Malang & 100.00 & 95.1 \\
Universitas Negeri Padang & 100.00 & 94.4 \\
Universitas Tanjungpura & 100.00 & 100.00 \\
Institut Teknologi Bandung & 100.00 & 100.00 \\
Institut Teknologi Sepuluh November & 100.00 & 94.4 \\
Universitas Negeri Jakarta & 100.00 & 100.00 \\
Universitas Negeri Medan & 100.00 & 100.00 \\
Universitas Negeri Yogyakarta & 100.00 & 71.4 \\
& & \\
\hline
\end{tabular}

Sumber: Evaluasi Program Studi Berbasis Evaluasi Diri (EPSBED), data diolah, 2008

Tabel 4

Perbandingan Hasil Pengolahan Model CRS dan Model VRS Tahun 2005

\begin{tabular}{lrr}
\hline Unit Nama & Pengolahan Model CRS & Pengolahan Model VRS \\
\hline Universitas Nusa Cendana & 100.00 & 53.2 \\
Universitas Andalas & 100.00 & 100.00 \\
Universitas Diponegoro & 100.00 & 100.00 \\
Universitas Gadjah Mada & 100.00 & 100.00 \\
Universitas Indonesia & 100.00 & 100.00 \\
Universitas Lambung Mangkurat & 100.00 & 82.9 \\
Universitas Sumatera Utara & 100.00 & 100.00 \\
Universtas Brawijaya & 100.00 & 100.00 \\
Universitas Jember & 100.00 & 94.3 \\
Universitas Jenderal Soedirman & 100.00 & 100.00 \\
Universitas Lampung & 100.00 & 100.00 \\
Universitas Mulawarman & 100.00 & 100.00 \\
Universitas Negeri Malang & 100.00 & 100.00 \\
Universitas Negeri Padang & 100.00 & 100.00 \\
Universitas Riau & 100.00 & 69.6 \\
Universitas Tanjungpura & 100.00 & 97.6 \\
Institut Teknologi Bandung & 100.00 & 100.00 \\
Institut Teknologi Sepuluh November & 100.00 & 100.00 \\
Universitas Negeri Jakarta & 100.00 & 100.00 \\
Universitas Negeri Medan & 100.00 & 100.00 \\
\hline
\end{tabular}


Universitas Negeri Yogyakarta

100.00

Sumber: Evaluasi Program Studi Berbasis Evaluasi Diri (EPSBED), data diolah, 2008

Tabel 5

Perbandingan Hasil Pengolahan Model CRS dan Model VRS Tahun 2005

\begin{tabular}{lrr}
\hline Unit Nama & Pengolahan Model CRS & Pengolahan Model VRS \\
\hline Universitas Nusa Cendana & 100.00 & 53.2 \\
Universitas Andalas & 100.00 & 100.00 \\
Universitas Diponegoro & 100.00 & 100.00 \\
Universitas Gadjah Mada & 100.00 & 100.00 \\
Universitas Indonesia & 100.00 & 100.00 \\
Universitas Lambung Mangkurat & 100.00 & 82.9 \\
Universitas Sumatera Utara & 100.00 & 100.00 \\
Universtas Brawijaya & 100.00 & 100.00 \\
Universitas Jember & 100.00 & 94.3 \\
Universitas Jenderal Soedirman & 100.00 & 100.00 \\
Universitas Lampung & 100.00 & 100.00 \\
Universitas Mulawarman & 100.00 & 100.00 \\
Universitas Negeri Malang & 100.00 & 100.00 \\
Universitas Negeri Padang & 100.00 & 100.00 \\
Universitas Riau & 100.00 & 69.6 \\
Universitas Tanjungpura & 100.00 & 97.6 \\
Institut Teknologi Bandung & 100.00 & 100.00 \\
Institut Teknologi Sepuluh November & 100.00 & 100.00 \\
Universitas Negeri Jakarta & 100.00 & 100.00 \\
Universitas Negeri Medan & 100.00 & 100.00 \\
Universitas Negeri Yogyakarta & 100.00 & 82.8 \\
& &
\end{tabular}

Sumber: Evaluasi Program Studi Berbasis Evaluasi Diri (EPSBED), data diolah, 2008

Tabel 6

Perbandingan Hasil Pengolahan Model CRS dan Model VRS Tahun 2006

\begin{tabular}{lrr}
\hline Unit Nama & Pengolahan Model CRS & Pengolahan Model VRS \\
\hline Universitas Nusa Cendana & 100.00 & 81.9 \\
Universitas Airlangga & 100.00 & 100.00 \\
Universitas Andalas & 100.00 & 100.00 \\
Universitas Diponegoro & 100.00 & 100.00 \\
Universitas Gadjah Mada & 100.00 & 100.00 \\
Universitas Indonesia & 100.00 & 100.00 \\
Universitas Lambung Mangkurat & 100.00 & 100.00 \\
Universitas Sumatera Utara & 100.00 & 100.00 \\
Universitas Syiah Kuala & 100.00 & 100.00 \\
Universtas Brawijaya & 100.00 & 100.00 \\
Universitas Jember & 100.00 & 100.00 \\
Universitas Jenderal Soedirman & 100.00 & 100.00 \\
Universitas Lampung & 100.00 & 100.00 \\
Universitas Negeri Malang & 100.00 & 96.1 \\
Universitas Negeri Padang & 100.00 & 96.0 \\
Universitas Tanjungpura & 100.00 & 100.00 \\
Institut Teknologi Bandung & 100.00 & 100.00 \\
Institut Teknologi Sepuluh November & 100.00 & 100.00 \\
Universitas Negeri Medan & 100.00 & 100.00 \\
Universitas Negeri Yogyakarta & 100.00 & 100.00 \\
& 100.00 & 87.4
\end{tabular}

Sumber: Evaluasi Program Studi Berbasis Evaluasi Diri (EPSBED), data diolah, 2008 
Dari tabel 1, 2, 3, 4, 5, dan 6 dapat dilihat bahwa hasil efisiensi relatif pada perhitungan dengan model CCR (CRS) lebih banyak yang sama dengan model VRS, maka model CCR sudah cukup, dan tidak perlu mengolah data DEA dengan model VRS. Dari tabel-tabel di atas juga bisa dilihat bahwa Perguruan Tinggi Negeri (PTN) yang terus efisien $100 \%$ selama 2002-2006 berdasarkan model CRS dan VRS antara lain: Universitas Andalas, Universitas Gadjah Mada, Universitas Sumatera Utara, dan Institut Teknologi Bandung.

\section{Simpulan dan Saran}

Tujuan penelitian ini adalah untuk menganalisis efisiensi Perguruan Tinggi Negeri (PTN) di Indonesia setelah diberlakukannya otonomi kampus. Kesimpulan dalam penelitian ini adalah beberapa Perguruan Tinggi Negeri di Indonesia sudah efisien selama lima tahun berturutturut (dari tahun 2002 sampai dengan 2006) antara lain: Universitas Andalas, Universitas Gajah Mada, Universitas Sumatera Utara dan Institut Teknologi Bandung.

Perlu adanya penelitian lain dengan mempergunakan metode penelitian yang berbeda guna lebih melengkapi hasil penelitian ini serta kemungkinan penambahan waktu serta data di lapangan.

\section{Daftar Referensi}

A.T. Flegg, D.O. Allen, K.Feld, T.W Thurlow. 2004. Measuring the Efficiency and Productivity of British Universities: An Application of DEA and the Malmquist Approach. REPEC working Paper. http://ideas.repec.org/p/uwe/wpaper/0304.html

Denizer, A. Cevdet and Dinc Mustafa. 2000. Measurung Banking Efficiency in the pre and Post Liberalization Environment: Evidence from the Turkish Banking System

Erwinta Siswadi dan Wilson Arafat, 2004, Mengukur Efisiensi Relatif Kantor Cabang Bank dengan Metode DEA, Jurnal Usahawan. Vol. XXXII, No. 10

Etty Puji Lestari. 2001. Efisiensi Teknik Perbankan di Indonesia tahun 1995-1999: Aplikasi Data Envelopment Analysis. Tesis Program Pasca Sarjana UGM, tidak dipublikasikan. Yogyakarta

Indah Susantun. 2000. Fungsi Keuntungan Cobb Douglas Dalam Pendugaan Efisiensi Ekonomi Relatif. Jurnal Ekonomi Pembangunan. Vol.5 no.2.

Melville L. McMillan dan Debasish Datta. 1998. The Relative Efficiencies of Canadian Universities: A DEA Perspective. Canadian Public Policy_Analyse de Politiqus. vol.xxiv, No.4.

Nicholson, W. 1999. Teori Ekonomi Mikro. PT. Raja Grafindo Persada. Jakarta.

Salvatore, D. 1996. Teori Ekonomi Mikro. Penerbit Erlangga. Jakarta.

Samsubar Saleh. 1999. Data Envelopment Analysis (DEA): Konsep Dasar. PAU-SE UGM. Yogyakarta.

Soekartawi. 2003. Teori Ekonomi Produksi dengan Pokok Bahasan Analisis Fungsi CobbDouglas. PT. Pusaka. LP3ES. Jakarta.

Staffan Waldo. 2002. Efficiency in Public Education. Repec Working Paper JEL: 121.

Tati, SJ dan M. Fathorozy. 2003. Teori Ekonomi Mikro. Salemba Empat, Jakarta.

*Ngatindriatun dan Hertiana Ikasari adalah Dosen Fakultas Ekonomi Universitas Dian Nuswantoro Semarang. 